\title{
PENGARUH LOCUS OF CONTROL TERHADAP HASIL BELAJAR MAHASISWA AKUNTANSI
}

\author{
Oleh : \\ Bety Nur Achadiyah \\ Nujmatul Laily \\ Universitas Negeri Malang \\ bety.achadiyah@um.ac.id
}

\begin{abstract}
Abstrak
Locus of Control adalah bentuk psikologi yang berarti kepercayaan seseorang tentang apa yang menyebabkan keberuntungan atau ketidakberuntungan dalam kehidupannya (Rotter, 1996). Penelitian ini dilakukan untuk mengetahui bagaimana perilaku belajar mahasiswa yang merupakan bagian kehidupan mereka dengan menggunakan basis karakter kepribadian, waktu belajar yang pasti dan gaya belajar mereka terhadap hasil belajar yang diproksikan dengan nilai Ujian Akhir Semester mahasiswa. Untuk melaksanakan penelitian ini, digunakan 50 model pernyataan dari Rotter (1996) dengan menggunakan skala likert empat poin. Populasi dari penelitian ini adalah seluruh mahasiswa akuntansi Universitas Negeri Malang dan sampel yang diambil sebanyak 193 responden. Metode penyampelan menggunakan convenience method. Hasil penelitian menunjukkan bahwa internal locus of control berpengaruh secara signifikan terhadap hasil belajar mahasiswa namun penelitian ini tidak berhasil membuktikan hubungan antara external locus of control dan hasil belajar mahasiswa.
\end{abstract}

Kata kunci: Locus of Control, Hasil Belajar

\begin{abstract}
Locus of Control is a term in psychology which refers to person's belief about what causes the good or bad results in his or her life (Rotter, 1996). Locus of control, according to Rotter's approach, can be divided into two separate sources of control: internal and external. This study is designed to explore about how the students learning behavior, which is a part of their life on the basis of personality characteristics, fixed learning time and their learning style. For conducting this study, 50 modified statements are used from Rotter's Locus of Control scale with four points likert scale. Population of this research are Accounting students in State University of Malang. By 193 responden were taken as samples. Sampling methode was done by convenience. The result shows that internal locus of control have significant effect on student's achievement but this research can't prove correlation between external locus of control and student's achievement.
\end{abstract}

Keywords: Locus of Control, Students’ Achievement 


\section{A. PENDAhULUAN}

Mahasiswa memiliki perilaku belajar yang berbeda-beda dalam kegiatan belajarnya. Dapat dipastikan bahwa setiap mahasiswa memiliki teknik yang berbeda dalam menghadapi tes atau ujian di kelas mereka. Locus of control adalah konsep yang menjelaskan apakah seseorang merasa bahwa pengendalian hidup mereka berada dalam genggaman tangan mereka sendiri (internal locus of control) ataukah berada pada genggaman tangan orang atau hal lainnya (external locus of control) (Rotter, 1996). Locus of control adalah suatu istilah dalam psikologi yang menunjukkan kepercayaan seseorang mengenai apa penyebab halhal baik atau hal-hal buruk dalam kehidupannya, baik dalam hal-hal umum maupun hal-hal khusus seperti kesehatan atau akademik. Pemahaman konsep tersebut dikembangkan oleh Julian B. Rotter pada tahun 1954 dan sejak itu menjadi aspek penting dalam studi personalitas.

Locus of control menunjukkan tingkat kepercayaan seseorang bahwa seseorang dapat mengendalikan peristiwa-peristiwa yang mempengaruhi kehidupan seseorang. Locus of control berdasarkan pada pendekatan Rotter (1996) dapat dibagi menjadi dua sumber pengendalian yaitu internal dan eksternal. Seseorang dengan locus of control internal tinggi percaya bahwa hasil dari peristiwa-peristiwa terutama dipengaruhi oleh perilaku dan tindakannya sendiri. Sebaliknya seseorang dengan locus of control eksternal tinggi percaya bahwa nasib atau peruntungan yang menentukan peristiwa-peristiwa dalam hidup mereka, termasuk kesuksesan ataupun kegagalan. Seseorang yang memiliki locus of control internal tinggi memiliki pengendalian yang lebih baik terhadap perilaku mereka dan cenderung menunjukkan perilaku yang politis dibanding seseorang dengan locus of control eksternal. Seseorang dengan locus of control internal tinggi kemungkinan besar juga akan berusaha untuk mempengaruhi orang lain serta berasumsi bahwa usahanya akan berhasil. Seseorang dengan locus of control internal juga akan lebih aktif dalam mencari informasi dan pengetahuan mengenai situasi mereka daripada seseorang dengan locus of control eksternal. Kecenderungan untuk terlibat dalam perilaku politik juga lebih kuat pada seseorang dengan locus of control internal. Seseorang dengan locus of control internal percaya bahwa mereka sendiri yang menentukan nasibnya. Mereka juga percaya bahwa pengalaman mereka dikendalikan oleh keterampilan dan usaha mereka sendiri. Sebagai contoh, seseorang dengan locus of control internal tinggi akan berkata "semakin saya belajar, semakin tinggi nilai yang saya peroleh" (Gershaw, 1989).

Disisi lain, seseorang yang cenderung memiliki locus of control eksternal akan cenderung menghubungkan pengalamannya dengan nasib, kesempatan atau keberuntungan. Sebagai contoh jika seorang mahasiswa menghubungkan kesuksesan atau kegagalannya dengan nasib, nilai yang jelek dihubungkan dengan prosedur dosen yang tidak adil atau kehendak Tuhan, maka mahasiswa tersebut dapat dikatakan memiliki locus of control eksternal. Mahasiswa tersebut mungkin akan berkata "tidak peduli bagaimana giatnya saya dalam belajar, tetapi karena dosen tidak menyukai saya, maka saya yakin saya tidak akan pernah mendapat nilai yang baik". Mahasiswa semacam itu biasanya tidak pernah mau belajar dari pengalaman, karena mereka selalu menghubungkan kesuksesan dan kegagalan hanya berdasarkan nasib, mereka juga cenderung tidak memiliki perilaku yang persisten serta tidak memiliki pengharapan yang tinggi. 
Secara umum pengembangan locus of control berakar dari keluarga, budaya dan pengalaman masa lalu. Kebanyakan seseorang dengan locus of control internal berasal dari keluarga yang fokus pada usaha (effort), pendidikan (education) dan tanggungjawab (responsibility). Disisi lain, kebanyakan seseorang dengan locus of control eksternal berasal dari keluarga dengan status sosioekonomi yang rendah dengan pengendalian hidup yang kurang.

Keterampilan non kognitif dapat tertuang dalam berbagai bentuk yang sangat beraneka ragam dan penelitian bidang ekonomi yang fokus pada penilaian personalitas, keterampilan, preferensi dan perilaku sangat penting untuk dihubungkan dengan kajian psikologis karena faktor psikologis sangat dominan menguasai keterampilan non kognitif. Oleh sebab itu, locus of control sebagai satu ukuran keterampilan non kognitif digunakan secara umum dalam kajian psikologis dan sering juga digunakan dalam kajian ekonomi pada peran keterampilan non kognitif bagi outcome pasar tenaga kerja (Heckman et al., 2006; Judge and Bono, 2001; Andrisani, 1977, 1981; Osborne, 2000).

Penelitian yang dilakukan di Perancis oleh Dubois (2001) terhadap 200 mahasiswa S1 jurusan Psikologi di Universitas Nancy dan Caen menunjukkan bahwa internal dan ekternal locus of control berhubungan dengan reinforcement. Dubois (2001) mengembangkan pengukuran internal dan eksternal locus of control berdasarkan 50 model pernyataan Rotter (1996). Lebih lanjut, Grimes et al. (2004) meneliti tentang hubungan antara locus of control mahasiswa dengan hasil evaluasi belajar mereka pada matakuliah prinsip-prinsip ekonomi tradisional. Hasil penelitian tersebut menunjukkan bahwa mahasiswa dengan locus of control eksternal yang lebih tinggi menunjukkan hasil belajar yang lebih rendah dibandingkan dengan mahasiswa yang memiliki locus of control internal yang lebih tinggi. Mahasiswa dengan locus of control eksternal yang lebih tinggi cenderung menyalahkan dosen mereka ketika mereka mendapatkan nilai yang rendah.

Berdasarkan uraian tersebut, dapat disusun hipotesis sebagai berikut:

H1 : Terdapat pengaruh antara internal locus of control dengan hasil belajar mahasiswa jurusan Akuntansi.

H2 : Terdapat pengaruh external locus of control berpengaruh negatif terhadap hasil belajar mahasiswa jurusan Akuntansi.

\section{B. METODE PENELITIAN}

Tujuan dari penelitian ini adalah untuk menguji pengaruh dari locus of control internal dan locus of control eksternal sebagai variabel bebas terhadap hasil belajar mahasiswa Akuntansi sebagai variabel terikatnya. Populasi dari penelitian ini seluruh mahasiswa Jurusan Akuntansi Fakultas Ekonomi Universitas Negeri Malang, sedangkan sampelnya adalah 200 orang mahasiswa jurusan Akuntansi yang dipilih menggunakan metode convenience. Dalam teknik pengambilan tersebut, pengambilan sampel dilakukan secara non probabilitas berdasarkan pertimbangan kemudahan peneliti (Jogiyanto, 2007: 79).

Penelitian dilakukan di Fakultas Ekonomi Universitas Negeri Malang selama bulan Agustus sampai Desember 2012 dengan menyebarkan kuisioner. Sebanyak 200 mahasiswa telah berpartisipasi dalam penelitian ini. Partisipan terdiri dari 65 mahasiswa yang sedang menempuh perkuliahan Etika Bisnis dan Profesi, 70 mahasiswa sedang menempuh matakuliah Akuntansi Internasional, 29 mahasiswa 
yang sedang menempuh matakuliah Akuntansi Perbankan dan 29 mahasiswa sedang menempuh matakuliah Manajemen Investasi. Dari 200 kuisioner yang disebarkan, sebanyak 193 dianggap memenuhi syarat dan sisanya diabaikan.

Berikut adalah ringkasan jumlah sampel dalam penelitian ini:

\section{Tabel 1. Sampel Penelitian}

\begin{tabular}{|c|c|}
\hline Jurusan & Jumlah \\
\hline Mahasiswa Etika Bisnis dan Profesi Off I & 20 \\
\hline Mahasiswa Etika Bisnis dan Profesi Off N & 45 \\
\hline Mahasiswa Akuntansi Internasional Off SS & 41 \\
\hline Mahasiswa Akuntansi Internasional Off C & 29 \\
\hline Mahasiswa Akuntansi Perbankan Off C & 29 \\
\hline Mahasiswa Manajemen Investasi Off RR & 29 \\
\hline \multicolumn{2}{|l|}{ Dikurangi: } \\
\hline Responden yang tidak memenuhi syarat & (7) \\
\hline Jumlah & 193 \\
\hline
\end{tabular}

Penelitian ini menggunakan rancangan deskriptif korelasional. Penelitian korelasional bermaksud untuk mengungkapkan hubungan korelatif antar variabel, dan dengan demikian dalam rancangan penelitian korelational peneliti harus melibatkan paling tidak dua variabel (Sukmadinata, 2010:46). Penelitian ini menggunakan deskriptif korelasional sebab peneliti ingin mengetahui pengaruh antara variabel bebas (locus of control internal dan locus of control eksternal) dengan variabel terikat (hasil belajar mahasiswa jurusan akuntansi Fakultas Ekonomi Universitas Negeri Malang) serta mendeskripsikan kaitan antara locus of control internal, locus of control eksternal dan hasil belajar mahasiswa.

Adapun hubungan antara variabel dapat digambarkan sebagai berikut:

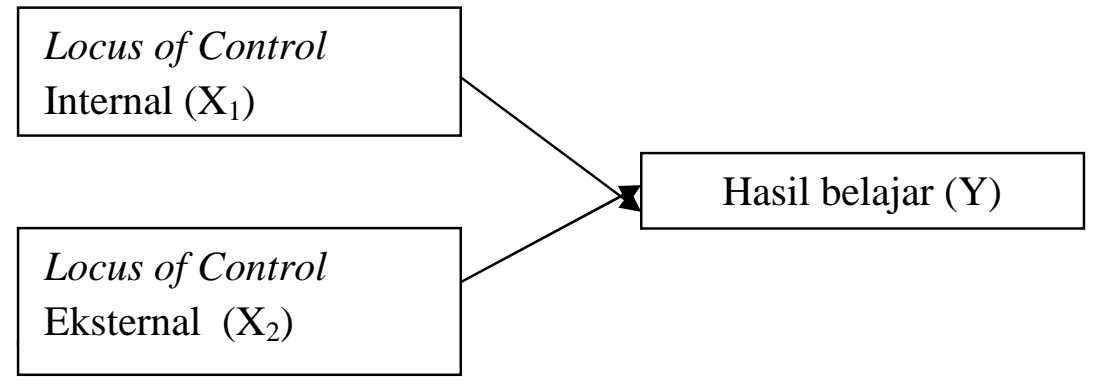

Pengukuran variabel locus of control internal dan ekternal menggunakan 50 model pernyataan dari Rotter (1996), sedangkan hasil belajar mahasiswa menggunakan nilai ujian tengah semester dan ujian akhir semester mahasiswa jurusan Akuntansi. Sebelum digunakan untuk mengumpulkan data, instrumen tersebut diujicobakan kepada mahasiswa akuntansi Universitas Negeri Malang lain yang tidak berperan menjadi subyek penelitian ini. Setelah diklarifikasi dan di coding, data yang terkumpul dianalisis secara kuantitatif yaitu dideskripsikan sesuai dengan fakta yang diperoleh. Skala pengukuran data yang dipergunakan dalam penelitian ini adalah skala likert, skala yang berhubungan dengan pernyataan atau sikap seseorang terhadap sesuatu dengan interval penilaian untuk setiap jawaban responden 1-4. Skala tersebut digunakan untuk mengukur 
Jurnal Pendidikan Akuntansi Indonesia, Vol. XI, No. 2, Tahun 2013

Bety Nur Achadiyah \& Nujmatul Laily

$11-18$

kedudukan locus of control internal dan eksternal dalam mempengaruhi motivasi belajar mahasiswa akuntansi.

Tabel 2: Jabaran Instrumen Penelitian

\begin{tabular}{|c|c|c|c|}
\hline Variabel & Indikator & Nomor Item & Jumlah \\
\hline $\begin{array}{l}\text { Variabel Bebas (X1): } \\
\text { Locus of Control } \\
\text { Internal }\end{array}$ & $\begin{array}{l}\text { 1. Percaya Diri } \\
\text { 2. Optimisme } \\
\text { 3. Pengalaman Hidup } \\
\text { 4. Kerja Keras } \\
\text { 5. Kepercayaan } \\
\text { Terhadap Nasib } \\
\text { 6. Rasionalitas }\end{array}$ & $\begin{array}{c}1,2,3 \\
4,5,6 \\
7,8,9 \\
10,11,12,13 \\
14,15,16,17 \\
18,19,20,21 \\
22,23,24,25 \\
\end{array}$ & $\begin{array}{l}3 \\
3 \\
3 \\
4 \\
4 \\
4 \\
4\end{array}$ \\
\hline $\begin{array}{l}\text { Variabel Bebas (X2): } \\
\text { Locus of Control } \\
\text { Eksternal }\end{array}$ & $\begin{array}{l}\text { 1. Percaya Diri } \\
\text { 2. Optimisme } \\
\text { 3. Pengalaman Hidup } \\
\text { 4. Kerja Keras } \\
\text { 5. Kepercayaan } \\
\text { Terhadap Nasib } \\
\text { 6. Rasionalitas } \\
\end{array}$ & $\begin{array}{c}1,2,3,4 \\
5,6,7,8 \\
9,10,11,12 \\
13,14,15,16 \\
17,18.29 \\
20,21,22 \\
23,24,25\end{array}$ & $\begin{array}{l}4 \\
4 \\
4 \\
4 \\
3 \\
3 \\
3\end{array}$ \\
\hline $\begin{array}{l}\text { Variabel Terikat (Y): } \\
\text { Hasil Belajar } \\
\text { Mahasiswa } \\
\text { Akuntansi }\end{array}$ & Nilai UTS dan UAS & & \\
\hline
\end{tabular}

Uji validitas dalam penelitian ini menggunakan pearson correlation dimana validitas dilihat dari tingginya korelasi masing-masing item pertanyaan dengan total skor pertanyaan. Jika korelasi tersebut signifikan maka dikatakan bahwa item pertanyaan tersebut valid. Hasil uji validitas menunjukkan bahwa terdapat empat item pertanyaan yang tidak valid. Hasil uji validitas ditunjukkan dalam tabel berikut:

Tabel 3. Hasil uji validitas

\begin{tabular}{|l|l|l|l|l|l|}
\hline Item & $\begin{array}{l}\text { Koefisien } \\
\text { Korelasi }\end{array}$ & Keterangan & Item & $\begin{array}{l}\text { Koefisien } \\
\text { Korelasi }\end{array}$ & Keterangan \\
\hline 1 & 0,322 & Valid & 26 & 0,321 & Valid \\
\hline 2 & 0,397 & Valid & 27 & 0,392 & Valid \\
\hline 3 & 0,411 & Valid & 28 & 0,345 & Valid \\
\hline 4 & 0,506 & Valid & 29 & 0,304 & Valid \\
\hline 5 & 0,372 & Valid & 30 & 0,322 & Valid \\
\hline 6 & 0,321 & Valid & 31 & 0,321 & Valid \\
\hline 7 & 0,341 & Valid & 32 & 0,392 & Valid \\
\hline 8 & 0,613 & Valid & 33 & 0,332 & Valid \\
\hline 9 & 0,497 & Valid & 34 & 0,433 & Valid \\
\hline 10 & 0,332 & Valid & 35 & 0,344 & Valid \\
\hline 11 & 0,319 & Valid & 36 & 0,456 & Valid \\
\hline 12 & 0,322 & Valid & 37 & 0,312 & Valid \\
\hline 13 & 0,397 & Valid & 38 & 0,366 & Valid \\
\hline 14 & 0,411 & Valid & 39 & 0,432 & Valid \\
\hline 15 & 0,506 & Valid & 40 & 0,520 & Valid \\
\hline 16 & 0,372 & Valid & 41 & 0,342 & Valid \\
\hline
\end{tabular}


Jurnal Pendidikan Akuntansi Indonesia, Vol. XI, No. 2, Tahun 2013

Bety Nur Achadiyah \& Nujmatul Laily

$11-18$

\begin{tabular}{|l|l|l|l|l|l|}
\hline Item & $\begin{array}{l}\text { Koefisien } \\
\text { Korelasi }\end{array}$ & Keterangan & Item & $\begin{array}{l}\text { Koefisien } \\
\text { Korelasi }\end{array}$ & Keterangan \\
\hline 17 & 0,303 & Valid & 42 & 0,378 & Valid \\
\hline 18 & 0,341 & Valid & 43 & 0,366 & Valid \\
\hline 19 & 0,613 & Valid & 44 & 0,344 & Valid \\
\hline 20 & 0,497 & Valid & 45 & 0,544 & Valid \\
\hline 21 & 0,322 & Valid & 46 & 0,433 & Valid \\
\hline 22 & 0,397 & Valid & 47 & 0,344 & Valid \\
\hline 23 & 0,441 & Valid & 48 & 0,556 & Valid \\
\hline 24 & 0,506 & Valid & 49 & 0,234 & Valid \\
\hline 25 & 0,302 & Valid & 50 & 0,366 & Valid \\
\hline
\end{tabular}

Penelitian ini juga telah melalui uji reliabilitas menggunakan pendekatan cronbach alpha. Hasil uji reliabilitas menunjukkan bahwa semua item reliabel karena berada diatas 0,6 sehingga dapat digunakan seluruhnya pada pengujian berikutnya. Hasil uji reliabilitas ditunjukkan pada tabel berikut:

Tabel 4. Hasil Uji Reliabilitas

\begin{tabular}{|l|c|c|c|}
\hline \multicolumn{1}{|c|}{ Variabel } & Jumlah Soal & Cronbach Alpha & Keterangan \\
\hline Locus of control internal & 25 & 0,734 & Reliabel \\
\hline Locus of control eksternal & 25 & 0,723 & Reliabel \\
\hline
\end{tabular}

\section{HASIL DAN PEMBAHASAN}

1. Pengaruh Locus of Control Internal terhadap Hasil Belajar Mahasiswa Akuntansi

Variabel locus of control internal dalam penelitian ini diukur dengan menggunakan beberapa indikator yang telah dijelaskan pada bagian sebelumnya. Indikator tersebut kemudian dikembangkan ke dalam 25 pertanyaan.

Berdasarkan deskripsi data dari penelitian dapat diketahui bahwa dari 193 responden yang diteliti, 107 responden dengan prosentase 55\% memiliki locus of control internal sangat tinggi. Selanjutnya sebanyak 53 responden dengan prosentase $28 \%$ memiliki locus of control internal tinggi, 23 responden dengan prosentase $12 \%$ memiliki locus of control internal kurang tinggi, serta 10 responden dengan prosentase 5\% memiliki locus of control internal rendah. Nilai locus of control internal tertinggi yang dimiliki oleh responden sebesar 98 sedangkan nilai terendahnya sebesar 25. Nilai rata-rata locus of control internal sebesar 72,86, nilai tersebut setara dengan kriteria tinggi dalam interval 51-75.

Tabel 5 Distribusi Frekuensi Nilai Locus of Control Internal

\begin{tabular}{cclcc}
\hline No & Interval & \multicolumn{1}{c}{ Kriteria } & Frekuensi & Prosentase \\
\hline 1 & $76-100$ & Sangat Tinggi & 107 & $55 \%$ \\
2 & $51-75$ & Tinggi & 63 & $33 \%$ \\
3 & $26-50$ & Kurang Tinggi & 13 & $7 \%$ \\
4 & $0-25$ & Rendah & 10 & $5 \%$ \\
\hline \multicolumn{2}{c}{ Jumlah } & $\mathbf{1 9 3}$ & $\mathbf{1 0 0 \%}$ \\
\hline
\end{tabular}

Penelitian ini menggunakan analisis regresi berganda dengan uji t. Dari hasil analisis data, diketahui untuk variabel locus of control internal di peroleh 
nilai B sebesar $0,027 \mathrm{t}$ hitung $(2,311)>\mathrm{t}$ tabel $(2,034)$ dengan probabilitas $(0,027)$ $\leq 0.05$ pada taraf signifikansi 5\%. Maka hipotesis Ho ditolak dan hipotesis alternatif $\mathrm{H}_{1}$ diterima. Sehingga dapat disimpulkan bahwa "terdapat pengaruh antara internal locus of control terhadap hasil belajar mahasiswa jurusan akuntansi". Hal tersebut mengindikasikan bahwa locus of control internal tinggi pengaruhnya terhadap pencapaian hasil belajar siswa jurusan akuntansi.

\section{Pengaruh Locus of Control Eksternal terhadap Hasil Belajar Mahasiswa Akuntansi}

Variabel locus of control eksternal dalam penelitian ini diukur dengan menggunakan beberapa indikator yang telah dijelaskan pada bab sebelumnya. Indikator tersebut kemudian dikembangkan ke dalam 25 pertanyaan.

Berdasarkan deskripsi data dari penelitian dapat diketahui bahwa dari 193 responden yang diteliti, 20 responden dengan prosentase $10 \%$ memiliki locus of control eksternal sangat tinggi. Selanjutnya sebanyak 40 responden dengan prosentase $21 \%$ memiliki locus of control eksternal tinggi, 114 responden dengan prosentase 59\% memiliki locus of control eksternal kurang tinggi, serta 19 responden dengan prosentase $10 \%$ memiliki locus of control eksternal rendah. Nilai locus of control eksternal tertinggi yang dimiliki oleh responden sebesar 79 sedangkan nilai terendahnya sebesar 26. Nilai rata-rata locus of control eksternal sebesar 45,85, nilai tersebut setara dengan kriteria kurang tinggi dalam interval 26-50.

Tabel 6 Distribusi Frekuensi Nilai Locus of Control Eksternal

\begin{tabular}{cclcc}
\hline No & Interval & \multicolumn{1}{c}{ Kriteria } & Frekuensi & Prosentase \\
\hline 1 & $76-100$ & Sangat Tinggi & 20 & $10 \%$ \\
2 & $51-75$ & Tinggi & 40 & $21 \%$ \\
3 & $26-50$ & Kurang Tinggi & 114 & $59 \%$ \\
4 & $0-25$ & Rendah & 19 & $10 \%$ \\
\hline \multicolumn{2}{c}{ Jumlah } & $\mathbf{1 9 3}$ & $\mathbf{1 0 0 \%}$ \\
\hline
\end{tabular}

Penelitian ini menggunakan analisis regresi berganda dengan uji t. Dari hasil analisis data, diketahui untuk variabel eksternal locus of control diperoleh koefisien B sebesar 0,210, $\mathrm{t}$ hitung $(1,594)<\mathrm{t}$ tabel $(2,034)$ dengan probabilitas $0,064 \geq 0,05$ pada taraf signifikansi $5 \%$. Maka hipotesis Ho diterima dan hipotesis alternatif $\mathrm{H}_{2}$ ditolak. Sehingga dapat disimpulkan bahwa, " tidak terdapat pengaruh antara eksternal locus of control terhadap hasil belajar mahasiswa". Hal tersebut mengindikasikan bahwa locus of control eksternal kurang tinggi pengaruhnya terhadap pencapaian hasil belajar siswa jurusan akuntansi.

\section{DAFTAR PUSTAKA}

Andrisani, P. 1981. Internal-External Attitudes, Personal Initiative, and The Labor Market Experience of Black and White Men. Journal of Human Resources, 12: 308-328.

Heckman, J., J. Stixrud, and S. Urzua. 2006. The effects of Cognitive and Noncognitive Abilities on Labor Market Outcomes and Social Behavior. Journal of Labor Economics, 24: 411-482. 
Jogiyanto, H.M. 2007. Metode Penelitian Bisnis: Salah Kaprah dan Pengalamanpengalaman. Yogyakarta: BPFE.

Judge, T. and J. Bono. 2001. Relayionship of Core Self-Evaluations Traits-Self Esteem, Generalizrd Self Efficacy, Locus of Control, and Emotional Stability With Job Satisfaction and Job Performance: A Meta Analysis. Journal of Applied Psychology, 86: 80-92.

Osborn, M. 2000. The Power of Personality: Labor Market Rewards and The Transmission or Earnings. Industrial and Labor Relationship Review: 6-26.

Rotter, J.B., 1996. Generalized Expectancies for Internal Versus External Control Reinforcement. Psycological Monographs, 80, No. 609.

Sukmadinata, Nana. 2004. Landasan Psikologi Proses Pendidikan. Bandung: Remaja Rosdakarya 